\title{
Pseudoexfoliation Syndrome Prevalence in Somali Patients with Senile Cataract
}

\author{
Senil Kataraktı Olan Somalili Hastalarda Psödoeksfoliasyon Sendromu Prevalansı
}

Mustafa Kalaycı

University of Health Sciences Turkey, Antalya Training and Research Hospital, Clinic of Ophthalmology, Antalya, Turkey

\begin{abstract}
Introduction: To evaluate the prevalence and demographic data of Pseudoexfoliation syndrome (PEX) in Somali patients with age-related cataract surgery.

Methods: The study included 110 eyes of 110 patients planned for undergoing cataract surgery. Slit lamp biomicroscopy was used for classifying the cataract as nuclear, cortical, mature or hypermature. Goldmann applanation tonometer was used to measure the intraocular pressure. The inclusion criteria were: age $>50$ years, surgical indication because of age-related cataract (severity of lens opacification $\geq 2$ in Lens Opacity Classification System III) and visual acuity $<3 / 10$. Pseudoexfoliation was defined as the presence of a differentlooking fibrillar white substance that formed an almost complete ring on the lens surface or on the pupillary edge.
\end{abstract}

Results: The prevalence of PEX was $40.9 \%$ (45/110). It was bilateral in $71.1 \%$ (32/45) of the cases. The mean age of the sample was $67.4 \pm 8.9$; however, that of patients with PEX (71.3 \pm 7.2 years) was significantly higher than in patients without it $(64.7 \pm 9$ years) $(p<0.05)$. The prevalence of PEX was higher in patients with mature cataract $(p<0.05)$ and older age $(p=0.01)$. Mean intraocular pressure was higher in eyes with pseudoexfoliation syndrome $(23.3 \pm 3.5 \mathrm{mmHg})$ than in those without it $(14.3 \pm 4.2 \mathrm{mmHg})$; and this finding was statistically significant $(\mathrm{p}<0.05)$.

Conclusion: PEX is a common condition in the Somali population. It is associated with ageing, mature and hypermature type of cataracts, glaucoma and increased intraocular pressure.

Keywords: Cataract, PEX, pseudoexfoliation, somalia, subsaharan africa

\section{$\ddot{0} Z$}

Amaç: Yaşa bağlı katarakt cerrahisi planlanan Somalili hastaları da psödoeksfolyasyon sendromu (PEX) prevalansını ve demografik verilerini değerlendirmekti.

Yöntemler: Çalıșmaya katarakt operasyonu için hazırlanan 110 hastanın 110 gözü dahil edildi. Katarakt tipi, yarık lamba biyomikroskopisi ile nükleer, kortikal, matur veya hipermatur olarak sınıflandırıldı. Hastaların göz içi basıncı, Goldmann aplanasyon tonometresi ile ölçüldü. Çalıșmaya dahil edilme kriterleri 50 yaşın üzerinde olma, yaşa bağlı katarakt tanısı nedeni ile cerrahi endikasyonu olma (Lens Opasite Sınıflandırma Sistemi III'de șiddetinin $\geq 2$ olması) ve görme keskinliğinin 3/10'un altında olmasıydı. Psödoeksfoliasyon, lens yüzeyinde veya pupiller kenarda neredeyse tam bir halka oluşturan farklı görünümlü fibriler beyaz bir maddenin varlığı olarak tanımlandı.

Bulgular: PEX prevalansı \%40,9 idi (45/110). Olguların \%71,1'inde (32/45) PEX bilateral idi. Yüz on olgunun ortalama yașı $67,4 \pm 8,9$ idi. PEX'li hastaların yaş ortalaması $(71,3 \pm 7,2$ yıl), olmayan hastaların yaş ortalamasından yüksekti $(64,7 \pm 9$ yıl) ve istatistiksel olarak anlamlıdı $(p<0,05)$. Matur kataraktlı hastalarda daha fazla PEX mevcuttu $(p<0,05)$. Ortalama göz içi basıncı, PEX'li gözlerde $(23,3 \pm 3,5 \mathrm{mmHg})$, PEX olmayan gözlere $(14,3 \pm 4,2 \mathrm{mmHg})$ göre daha yüksekti ve bu istatistiksel olarak anlamlıydı $(p<0,05)$.

Sonuç: Somali popülasyonunda PEX sık görülen bir durumdur. PEX yașlanma, matur ve hipermatur tipte katarakt, glokom ve artmış göz içi basıncı ile ilişkilidir.

Anahtar Kelimeler: Katarakt, PEX, psödoeksfoliasyon, somali, sahra altı afrika
Address for Correspondence/Yazıșma Adresi: Mustafa Kalaycı MD, University of Health Sciences Turkey, Antalya Training and Research Hospital, Clinic of Ophthalmology, Antalya, Turkey

Phone: +90242 2494400 E-mail: drkalayci07@hotmail.com ORCID ID: orcid.org/0000-0001-8056-6634

Cite this article as/Atıf: Kalaycı M. Pseudoexfoliation Syndrome Prevalence in Somali Patients with Senile Cataract. İstanbul Med J 2020; 21(5): 380-3
Received/Geliș Tarihi: 16.02 .2020 Accepted/Kabul Tarihi: 30.07 .2020

(C) Copyright 2020 by the University of Health Sciences Turkey, Istanbul Training and Research Hospital/istanbul Medical Journal published by Galenos Publishing House.

(c) Telif Hakkı 2020 Sağılk Bilimleri Üniversitesi Istanbul Ĕğitim ve Araştırma Hastanesi/Istanbul Tıp Dergisi, Galenos Yayınevi tarafından basılmıștır. 


\section{Introduction}

Pseudoexfoliation is a condition characterized by accumulation of extracellular fibrillar material in systemic tissues and eyes.It is present in the eye, on the lens surface, lens zonules, iris surface, corneal endothelium, trabecular meshwork, pupil edge and anterior hyaloid surface (1). Aging is an important risk factor in the development of Pseudoexfoliation syndrome (PEX) and cataracts. The incidence of PEX is positively correlated with age. Increased lens opacity has also been associated with PEX (2).

The presence of PEX is etiologically associated with cataract, lens subluxation, retinal vein occlusion, open-angle glaucoma, and closedangle glaucoma (3). In addition, it is known that the frequency of complications of zonular detachment, posterior capsule rupture and vitreous loss during cataract extraction in PEX eyes increases compared to normal eyes (4).

Pseudoexfoliation glaucoma is more severe than primary open-angle glaucoma in terms of clinical course and prognosis (5). Pseudoexfoliation glaucoma has much worse visual field and higher optic nerve damage during diagnosis than primary open-angle glaucoma. This may be due to higher and greater fluctuations in pseudoexfoliation glaucoma.

Epidemiological data on the prevalence of PEX is best obtained from population-based research, but useful information on the prevalence of PEX can be obtained from different subgroups of a population such as cases of cataracts and glaucoma (6).

Our clinical observation led us to believe that the prevalence of PEX among Somali people is relatively high. As a result of this situation, we aimed to investigate the prevalence of PEX in a prospective study in Somali patients who were scheduled to undergo cataract surgery.

\section{Methods}

This hospital-based prospective study was conducted according to the principles of the Declaration of Helsinki and received the approval of the Ethics Committee of the Recep Tayyip Erdoğan Training and Research Hospital of Somalia Mogadishu Turkey (decision no: 172, date: 25.11.2019). Written informed consent was obtained from the patients and their families before any examination or treatment was performed.

Our hospital, which is located in Mogadishu, the capital of Somalia and is the only tertiary health center in the country, is a reference hospital where patients are transferred from all over the country and was opened with the help of the Republic of Turkey to serve the entire Somali population. At the same time, the appointment of specialist doctors for the training of Somali assistant doctors is done by the Ministry of health of the Republic of Turkey temporarily and periodically (4 months). During November 2019 - February 2020, 110 eyes of 110 patients admitted to the eye outpatient clinic of Mogadishu Turkey Training and Research Hospital in Somalia with low vision, diagnosed with cataracts and prepared for the operation were included in this study. The age and gender of the patients were recorded. Cataract type of all patients were classified as nuclear, cortical, matur and hypermature by slit lamp biomicroscopy. Intraocular pressure (IOP) was measured with Goldmann aplanation tonometer.

The criteria to be included in the study were; being over 50 years of age, being a surgical indication for age-related cataract diagnosis (intensity $\geq 2$ in Lens Opacite Classification System III) and visual acuity below 3/10. Patients suspected of glaucoma (optic nerve head abnormalities, history of glaucoma and $I O P>21 \mathrm{mmHg}$ ) were screened for this disease according to the criteria of the International geographical and epidemiological Society of Ophthalmology (7). Patients with a history of eye trauma and/or surgery, congenital cataracts, drug-related cataracts, and uveitis-related cataracts were excluded from the study.

Pseudoexfoliation was described as the presence of a distinctive-looking fibrillar white substance that forms an almost complete ring on the lens surface or pupillary edge (8). All cases were examined by fundus with detailed optic nerve examination. Fully invisible nerves were evaluated using B-mode ultrasonography.

\section{Statistical Analysis}

Statistical analyses were performed using IBM SPSS version 23.0 (SPSS v.23.0, Illinois, USA). Comparisons between the two groups were calculated using the Pearson chi-square test. The frequency analysis was done by chi-square testing. $\mathrm{P}<0.05$ was considered statistically significant.

\section{Results}

The prevalence of PEX was 40.9\% (45 out of 110 eyes). In 71.1\% (32/45) of cases, PEX was bilateral. The mean age of 110 patients was $67.4 \pm 8.9$ years (51-88 years) (Table 1). The mean age of PEX patients (71.3 \pm 7.2 years) was significantly higher than the average age of non-PEX patients

Table 1. Prevalence of pseudoexfoliation syndrome by gender and age

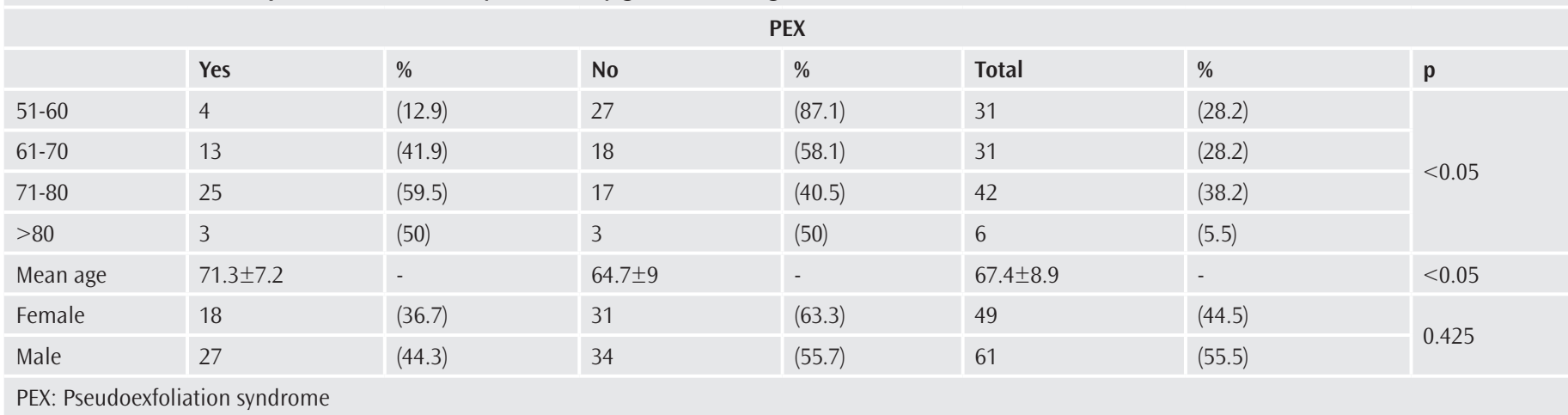


(64.7 \pm 9 years) $(p<0.05)$. PEX prevalence was positively correlated with age increase and this finding was statistically significant $(p=0.01)$. PEX was significantly higher in patients with matured cataracts $(p<0.05)$. The mean IOP was significantly higher in eyes with PEX $(23.3 \pm 3.5 \mathrm{mmHg})$ than eyes without PEX $(14.3 \pm 4.2 \mathrm{mmHg})(p<0.05)$. Patients with IOP $>21 \mathrm{mmHg}$ and glaucoma were higher in the PEX group and statistically significant $(p<0.05)$ (Table 2).

\section{Discussion}

Our study is the first study on PEX in Somalia. In this study, the frequency of PEX was $40.9 \%$ in patients preparing for cataract surgery. This finding was higher compared to other studies conducted in different populations. The prevalence of PEX was $10.7 \%$ (7) in Iceland, $16.4 \%$ (9) in Turkey, 22.1\% (10) in India, 25.2\% (11) in Finland, 27.9\% (12) in Greece and $39.3 \%$ (6) in Ethiopia. To date, many researchers have reported significant differences in the prevalence of PEX in the same country or close geographic area $(13,14)$. The reason for the large change in PEX prevalence in near and far populations is unclear. There have been studies (15) showing that exposure to ultraviolet radiation increases prevalence, but the high prevalence among Icelanders living near the North Pole does not support this hypothesis (16).

There was no significant difference in the gender distribution of PEX syndrome in our study, and this finding was similar to other studies in Japan (17), Australia (18) and Saudi Arabia (1). However, some research has indicated that it is more common in men and has linked this condition to men working more outdoors and being more exposed to ultraviolet radiation $(19,20)$.

Our study included patients over the age of 50 with PEX findings. In a hospital-based study that investigated the frequency of PEX in patients preparing for cataract surgery, it was reported that PEX was not seen under the age of 50 (21). In addition, hard cataracts are more common over the age of 50 (21). In our study, PEX frequency was $12.9 \%$ in the $51-60$ age group, $41.9 \%$ in the $61-70$ age group, $59.5 \%$ in the $71-80$ age group and $50 \%$ in the over 80 age group. The increase in PEX frequency relative to age was statistically significant $(p<0.05)$.

PEX patients in our study were significantly older than non-PEX patients. This finding was similar to the results of earlier research $(13,22)$. Compared to study results from other regions, PEX appears to occur at a relatively younger age in Africans (4). However, the average age of the patients with PEX was similar to the European average (23). One of the reasons that the age of the patients in our study was higher than in other studies in Africa is that Somali patients were often admitted to hospital for cataract surgery when their vision level was too low to do daily work. The most common type of cataract in our PEX patients was hypermature cataract (55.5\%), while in non-PEX patients (41.5\%), cortical cataract was the most common type. The proportion of mature and hypermature cataracts (49.1\%) was high due to late application. The increase in PEX rate was statistically significant as cataract stiffness increased $(p<0.05)$.

Although the relationship between PEX and cataract is not fully explained, some theories have been presented. The most widely accepted theory is that hypoxia, oxidative stress, ocular ischemia developing as a result of increased growth factor levels in aqueous fluid due to deterioration of the blood-aqueous fluid barrier and that this condition contributes simultaneously to the development of PEX and cataract (24).

Today, the relationship between PEX and glaucoma is well known. The prevalence of glaucoma in PEX patients was 13.3\% (6) in Ethiopia, 19\% (25) in South Africa, 28.8\% (26) in Greece, 32.1\% (9) in Turkey and 71\% in our study. The most important reason for this high rate in our study is that our institution is the only tertiary Hospital in the country and that patients with complicated cataracts that cannot be done in other centers are referred to our hospital.

Additionally, the average IOP was higher in PEX patients than in the non-PEX group, which was consistent with previous studies $(2,13,26)$ and statistically significant $(p<0.05)$. Based on these findings, the presence of PEX can be considered one of the main risk factors in the development of glaucoma.

The limitation of our study was that it was a hospital-based study and that the prevalence of PEX was assessed only in the population with cataracts. Therefore, the results of the study may not reflect the actual distribution of PEX in the Somali general population. Prospective community-based studies are needed to determine the optimal frequency of PEX in this area.

\section{Conclusion}

Our study confirms that PEX is a common condition in the Somali public. In our study, PEX was associated with aging, matured and hypermature type cataracts, glaucoma and increased IOP.

Table 2. Characteristics of Pseudoexfoliation syndrome and non-Pseudoexfoliation syndrome eyes (number of patients =110)

\begin{tabular}{|c|c|c|c|c|c|c|c|}
\hline \multicolumn{8}{|c|}{ PEX } \\
\hline & Yes & $\%$ & No & $\%$ & Total & $\%$ & $p$ \\
\hline Cortical cataract & 3 & $(10)$ & 27 & $(90)$ & 30 & (27.3) & \multirow{4}{*}{$<0.05$} \\
\hline Nuclear cataract & 4 & (84.6) & 22 & $(15.4)$ & 26 & $(23.6)$ & \\
\hline Mature cataract & 13 & $(56.5)$ & 10 & $(43.5)$ & 23 & $(20.9)$ & \\
\hline Hypermature cataract & 25 & (80.6) & 6 & $(19.4)$ & 31 & $(28.2)$ & \\
\hline IOP (mmHg) & $23.3 \pm 3.5$ & - & $14.3 \pm 4.2$ & - & $18 \pm 5.9$ & - & $<0.05$ \\
\hline Glaucoma (+) & 32 & $(71.1)$ & 7 & $(89.2)$ & 39 & $(35.5)$ & \multirow{2}{*}{$<0.05$} \\
\hline Glaucoma (-) & 13 & (28.9) & 58 & $(10.8)$ & 71 & (64.5) & \\
\hline
\end{tabular}




\section{Ethics}

Ethics Committee Approval: This hospital-based prospective study was conducted according to the principles of the Declaration of Helsinki and received the approval of the Ethics Committee of the Recep Tayyip Erdoğan Training and Research Hospital of Somalia Mogadishu Turkey (decision no: 172, date: 25.11.2019).

Informed Consent: Written informed consent was obtained from the patients and their families before any examination or treatment was performed.

Peer-review: Externally peer-reviewed.

Financial Disclosure: The author declared that this study received no financial support.

\section{References}

1. Al-Saleh S, Al-Dabbagh N, Al-Shamrani S, Khan N, Arfin M, Tariq M, et al. Prevalence of ocular pseudoexfoliation syndrome and associated complications in Riyadh, Saudi Arabia. Saudi Med J 2015; 36: 108-12.

2. Kaljurand K, Puska P. Exfoliation syndrome in Estonian patients scheduled for cataract surgery. Acta Ophthalmol Scand 2004; 82: 259-63.

3. Ritch R, Schlötzer-Schrehardt U. Exfoliation Syndrome. Surv Ophthalmol 2001; 45: 265-315.

4. Olawoye 00, Pasquale LR, Ritch R. Exfoliation syndrome in sub-Saharan Africa. Int Ophthalmol [Internet] 2014; 34: 1165-73.

5. Futa R, Shimizu T, Furuyoshi N, Nishiyama M, Hagihara O. Clinical features of capsular glaucoma in comparison with primary open-angle glaucoma in Japan. Acta Ophthalmol (Copenh) 2009; 70: 214-9.

6. Teshome T, Regassa K. Prevalence of pseudoexfoliation syndrome in Ethiopian patients scheduled for cataract surgery. Acta Ophthalmol Scand 2004; 82: 254-8.

7. Arnarsson A, Damji KF, Sverrisson T, Sasaki H, Jonasson F. Pseudoexfoliation in the Reykjavik Eye Study: prevalence and related ophthalmological variables. Acta Ophthalmol Scand 2007; 85: 822-7.

8. Schlötzer-Schrehardt U, Naumann GOH. Ocular and Systemic Pseudoexfoliation Syndrome. Am J Ophthalmol 2006; 141: 921-37.

9. Sekeroglu MA, Bozkurt B, Irkec M, Ustunel S, Orhan M, Saracbasi O. Systemic Associations and Prevalence of Exfoliation Syndrome in Patients Scheduled for Cataract Surgery. Eur J Ophthalmol 2008; 18: 551-5.

10. Joshi R, Singanwad S. Frequency and surgical difficulties associated with pseudoexfoliation syndrome among Indian rural population scheduled for cataract surgery: Hospital-based data. Indian J Ophthalmol 2019; 67: 221-6.

11. Hietanen J, Kivelä T, Vesti E, Tarkkanen A. Exfoliation syndrome in patients scheduled for cataract surgery. Acta Ophthalmol (Copenh) 2009; 70: 440-6.
12. Andrikopoulos GK, Mela EK, Georgakopoulos CD, Papadopoulos GE, Damelou AN, Alexopoulos DK, et al. Pseudoexfoliation syndrome prevalence in Greek patients with cataract and its association to glaucoma and coronary artery disease. Eye 2009; 23: 442-7.

13. Wålinder P-EK, Olivius EOP, Nordell SI, Thorburn WE. Fibrinoid reaction after extracapsular cataract extraction and relationship to exfoliation syndrome. J Cataract Refract Surg 1989; 15: 526-30.

14. Ritland JS, Egge K, Lydersen S, Juul R, Semb SO. Exfoliative glaucoma and primary open-angle glaucoma: associations with death causes and comorbidity. Acta Ophthalmol Scand 2004; 82: 401-4.

15. Pasquale LR, Jiwani AZ, Zehavi-Dorin T, Majd A, Rhee DJ, Chen T, et al. Solar Exposure and Residential Geographic History in Relation to Exfoliation Syndrome in the United States and Israel. JAMA Ophthalmol 2014; 132: 143945.

16. Arnarsson ÃM. Epidemiology of exfoliation syndrome in the Reykjavik Eye Study. Acta Ophthalmol 2009; 87: 1-17.

17. Miyazaki M, Kubota T, Kubo M, Kiyohara Y, lida M, Nose Y, et al. The Prevalence of Pseudoexfoliation Syndrome in a Japanese Population. J Glaucoma 2005; 14: $482-4$.

18. Mccarty CA, Taylor HR. Pseudoexfoliation syndrome in Australian adults. Am J Ophthalmol 2000; 129: 629-33.

19. Al-Shaer M, Bamashmus M, Al-Barrag A. Point prevalence of pseudoexfoliation syndrome in patients scheduled for cataract surgery in eye camps in yemen. Middle East Afr J Ophthalmol 2010; 17: 74-7.

20. Idakwo U, Olawoye O, Ajayi BG, Ritch R. Exfoliation syndrome in Northern Nigeria. Clin Ophthalmol 2018; 12: 271-7.

21. Govetto A, Lorente R, de Parga PV, Rojas L, Moreno C, Lagoa F, et al. Frequency of pseudoexfoliation among patients scheduled for cataract surgery. J Cataract Refract Surg 2015; 41: 1224-31.

22. Konstas AGP, Tsironi S, Ritch R. Current concepts in the pathogenesis and management of exfoliation syndrome and exfoliative glaucoma. Compr Ophthalmol Update 2006; 7: 131-41.

23. Anastasopoulos E, Topouzis F, Wilson MR, Harris A, Pappas T, Yu F, et al. Characteristics of Pseudoexfoliation in the Thessaloniki Eye Study. J Glaucoma 2011; 20: 160-6.

24. Damji KF, Bains HS, Stefansson E, Loftsdottir M, Sverrisson T, Thorgeirsson $\mathrm{E}$, et al. Is pseudoexfoliation syndrome inherited? A review of genetic and nongenetic factors and a new observation. Ophthalmic Genet 1998; 19: 17585 .

25. Bartholomew RS. Pseudocapsular exfoliation in the Bantu of South Africa. II. Occurrence and prevalence. Br J Ophthalmol 1973; 57: 41-5.

26. Kozobolis VP, Papatzanaki M, Vlachonikolis IG, Pallikaris IG, Tsambarlakis IG. Epidemiology of pseudoexfoliation in the island of Crete (Greece). Acta Ophthalmol Scand 2009; 75: 726-9. 